\title{
Development and Performance Evaluation of Solar Photovoltaic Module's Surface-to-Rear Temperature Controlled Valve for Cooling Application
}

\author{
M. Mawoli ${ }^{1,2 *}$, H.N. Yayha ${ }^{3}$, B. G. Danshehu ${ }^{4}$, M. L. Muhammad ${ }^{5}$, A. S. Bature ${ }^{1}$ \\ ${ }^{1}$ Sokoto Energy Research Centre, Usmanu Danfodiyo University Sokoto, Nigeria. \\ ${ }^{2}$ Department of Physics, Usmanu Danfodiyo University Sokoto, Nigeria. \\ ${ }^{3}$ Department of Electrical/Electronics Engineering, Usmanu Danfodiyo University Sokoto, Nigeria. \\ ${ }^{4}$ Department of Mechanical Engineering, Usmanu Danfodiyo University Sokoto, Nigeria. \\ ${ }^{5}$ Department of Pure and Applied Chemistry, Usmanu Danfodiyo University Sokoto, Nigeria.
}

ABSTRACT: This study investigated the effectiveness of the developed solar photovoltaic (PV) module's surface-torear temperature-controlled solenoid valves for PV module cooling application. The cooling fluid is regulated by energizing normally closed (NC) solenoid valve with control parameters as modules rear and surface temperatures. ATmega32 microcontroller was utilized as central processing unit with two (2) LM35 as input sensors and solenoid valve as an output device. Each of 2-LM35 temperature sensors were dedicated to measure module's rear and surface temperatures respectively. The measured temperature values were coded as controlled parameters for regulating cooling fluid discharge by energizing a NC solenoid valve. The system was observed to discharge cooling fluid by energizing the solenoid valve under module's surface and rear temperature difference of less than or equal to $1.5^{\circ} \mathrm{C}$ $\left(\mathrm{T}_{\mathrm{s}}-\mathrm{T}_{\mathrm{r}} \leq 1.5^{\circ} \mathrm{C}\right)$. The module's mean surface temperatures of $49.31^{\circ} \mathrm{C}$ and $54.92^{\circ} \mathrm{C}$ were recorded for temperaturecontrolled PV cooling applications and a standard solar photovoltaic/thermal (PV/T) system. The maximum recorded surface temperatures for temperature-controlled PV cooling and a standard PV/T systems were $54.0^{\circ} \mathrm{C}$ and $57.6^{\circ} \mathrm{C}$ respectively. The mean absorber temperatures of $45.51^{\circ} \mathrm{C}$ and $40.87^{\circ} \mathrm{C}$ were respectively recorded for temperaturecontrolled PV cooling and standard PV/T. The maximum absorber temperature recorded for temperature-controlled PV cooling and standard PV/T were $48.30^{\circ} \mathrm{C}$ and $41.63^{\circ} \mathrm{C}$ respectively. The solar cells temperature is reduced by $5.38 \%$ through solenoid valve temperature controlled solar module cooling application.

KEYWORDS: Temperature-controlled, ATmega32, solenoid valve, solar module, cooling application.

[Received March 22, 2019, Revised July 8, 2019, Accepted October 29, 2019]

Print ISSN: 0189-9546 | Online ISSN: 2437-2110

\section{INTRODUCTION}

Photovoltaic (PV) panels are designed to convert solar radiation into direct current (DC). Only $5-20 \%$ of the incident energy is converted into electricity, depending on the PV cell technology used (Wim et al., 2004). Solar cell temperature is among one of the most critical factors that affects the efficiency of solar cells (Dinçer and Meral, 2010). Most significant change by temperature is voltage which decreases with increasing temperature, while output current slightly increases by temperature (Tobnaghi et al., 2013). However, the cumulative effect is reduction in power output.

In an attempt to regulate the elevated surface temperature of solar module, solar photovoltaic/thermal (PV/T) systems were developed. These systems are either in passive or active form. These systems are capable of providing thermal energy and improved output power. Passive solar PV/T systems use natural convection to transport the fluid from the heat exchanger attached to solar modules to the storage tank, whereas, the active systems require pump to force the fluid to circulate from the heat exchanger to the rest part of the system. Passive systems are less expensive and easier to develop than the active systems. However, passive PV/T systems are associated with efficient hot water circulation Tsoho (2014).

A study on the performance investigation of photovoltaic modules by back surface water cooling was conducted by Bashir et al. (2018). In their study, two modules were modified by making ducts at their back surface having inlet and outlet manifolds for water flow with measurement taken with cooling and without cooling. Obviously, their study adopted a passive type cooling where an electromechanical pump is not integrated or utilized for water circulation.

Ceylan et al. (2013) conducted an experimental study on hybrid solar PV - solar thermal system aimed at improving the conversion efficiency of PV module and subsequently providing electricity and hot water. The cooling fluid is preheated through heat exchanger attached to solar PV module and subsequently channeled to solar collector for a preset temperature value from the outlet end of solar PV module. A normally closed solenoid valve is program to open at certain temperature value to further transport preheated fluid to a solar collector for adequate heating. This study employs one temperature sensor for solenoid control. The solar PV system and solar collector were both developed as separate entity. 
In another study conducted by Claros-Marfil et al. (2016), a data acquisition and a controller were developed for solar research. The controller is designed to govern the pump, the solenoid valve and the heater for water-flow glazing application in particular. An Arduino Mega ADK (Android Development Kit) was considered in their study. However, the application is limited to solar water heating with water a lone temperature data for valve control. In addition, wire or thermocouple was used as a temperature sensor in their design.

In a similar study conducted by Kumar et al. (2017), two separate systems comprising solar PV and solar distiller were developed and integrated with the aim of cooling the solar module and subsequently provides distilled water. The system incorporated controller for regulating the operations of solenoid valves, DC pump and switch. The solenoid valves were connected in-between the saline water storage tank and solar module, and solar module and distillate collector. DC pump is connected to channel the water from distillate collector back to solar module for continuous water circulation in the system. However, the preheated water which is responsible for PV module cooling was controlled by a regulated time interval.

Calebe et al. (2017) carried out a study on increasing photovoltaic panel power through water cooling technique with water circulation been controlled by water valve. In this study, the water valve is uncontrolled electronically. The data were collected with PC via serial link RS-232 and the experiment was conducted in a controlled environment, unlike in the current study where the panel is subjected to real life microclimatic condition of Sokoto. Furthermore, unlike in the current study where cooling is through the use of heat exchanger attached to the back-side of solar module, Calebe et al. (2017) adopted surface cooling, in which case the water is applied on the front surface of the panel at different flow rate.

Rawat (2014) narrowed down their study on the design, development and experimental investigation of solar photovoltaic/thermal (PV/T) water collector system using $37 \mathrm{~W}$ polycrystalline silicon solar panel as a collector. An $18 \mathrm{~W}$ AC pump was used to provide $0.002 \mathrm{~kg} / \mathrm{sec}$ constant mass flow rate of water circulation within the system and the readings were taken every one hour. In other words, the pump is continuously power over the period of active sunshine and irrespective of the intensity of solar radiation. This may not effectively provide cooling and it may add up to the cost of powering the active pump, as the pump was not conditioned to $\mathrm{ON}$ or OFF with respect to the intensity of solar radiation or the rate of absorption of heat from PV module. Their findings have shown that the daily electrical efficiency was about $7.57 \%$, the daily thermal efficiency was about $50.1 \%$, and the total efficiency of the system exceeded $73 \%$.

Kaya (2013) carried out a study on thermal and electrical performance evaluation of $\mathrm{PV} / \mathrm{T}$ collectors in $\mathrm{UAE}$ with a variable power $(40 \mathrm{~W}, 70 \mathrm{~W}, 115 \mathrm{~W})$ pump for continuous water circulation and observed that by combining thermal and electrical aspects of solar panels, an increase in electrical output is experienced due to the reason that the water circulation through the collector decreases the overall temperature of solar cells, which lead to a performance increase in terms of electricity production. This is to imply that the pumps were not controlled to provide a variable flow rate, rather three different pumps of different variable power (i.e. with different flow rate) were utilized in order to study the effect of varied flow rate on the PV module performance. In our study, the flow of water was provided through gravity and water discharge is regulated by interment ON/OFF of the solenoid valve. This valve control is conditioned with respect to water temperature and the module surface temperature.

A comparative analysis studies conducted by Khan et al. (2017) adopted four different cooling methods and a bireflector for the investigation of the effect of cooling on the performance of photovoltaic solar system. The proposed cooling techniques include passive air cooled, closed loop water loop, air cooled and water sprinkling systems respectively. The bi-reflectors were positioned opposite each for increasing the amount of light intensity on the PV module. For passive air cooled system, heat sinks are installed on the rear side of the solar module for improve on the natural or convective cooling. Closed loop water loop system integrated a (for cool water circulation) at the rear side of the module with a flow meter connected to regulate the flow rate and pump for the circulation of hot water. Neither the pump nor the flow meter was controlled. For the air cooling method, a brushless DC fan was utilized, whereas water sprinkling system sprinkle water on the surface of PV module for cooling to take effect. However, it was not clear whether the sprinkling was intermittent or continuous (i.e. controlled or uncontrolled).

In a similar study, Kabeel et al. (2019) subjected PV module with reflectors to Egyptian conditions using three different cooling techniques. These techniques include air forced cooling technology, water cooling technology and combined forced-air and water cooling technology, with all in the presence of reflectors. The description of the system is similar to the study conducted by Khan et al. (2017) with the exception that a combined forced-air and water cooling technique utilizes simultaneous supply of forces-air and water by $10 \mathrm{~W}$ DC blower and a $5 \mathrm{~W}$ DC pump with their respective flow rate as $61 \mathrm{~m}^{3} / \mathrm{h}$ and $12 \mathrm{~L} / \mathrm{min}$. This also was uncontrolled by temperature parameters.

Castanheira et al. (2017) demonstrated a project for a cooling system for existing PV power plants in Portugal where water cooling kit system was designed and characterized specifically for the already existing and operational $20 \mathrm{~kW} \mathrm{PV}$ plants. In their study, a water sprinkler is designated per string of PV panels and these sprinklers were intermittently operated through a controlled valve that is connected in-between a pump and the sprinklers. The average ON and OFF thermal constants were 0.6 and 11 minutes respectively. This is a clear indication the controlled valves were temperature uncontrolled.

Dorobanţu et al. (2013) carried out an experimental assessment of PV panels front water cooling strategy and concluded that free flow water cooling of PV panels could improves the efficiency and reliability of photovoltaic energy conversion - the open voltage of the panels was increasing when its temperature decrease and due to the lower operating 
temperature, its life cycle could be increased. The current study adopted controlled back-side cooling.

The associated challenges with an active and passive PV/T system are continuous power consumption and inefficient hot water circulation. The surface-to-rear temperature-controlled NC solenoid valve is developed to accurately determine when to discharge the cooling fluid within the heat exchanger in order to avoid further heating up of solar cells.

\section{MATERIALS AND METHODS}

This system combined hardware and software for proper system's functioning. The hardware unit is subdivided into two major subunits, namely: temperature sensing unit and valves regulating unit. Software is a program developed for accurate hardware's control and communication. The controlled program was developed and compiled using Atmel Studio 6.2. Liquid crystal display, LCD and keypad (control buttons) are also integrated system's hardware units which serve as a user's interface and a means of debugging.

A. LM35 Temperature Sensing Unit

Solar modules surface temperature variation is unlikely to be greater than $150^{\circ} \mathrm{C}$ in any part of the world. LM35 precision centigrade temperature sensors is rated for full $-55^{\circ} \mathrm{C}$ to $150^{\circ} \mathrm{C}$ range. LM35 is therefore selected for this application. Furthermore, the LM35 device does not require any external calibration to provide accuracies of $\pm 1 / 4^{\circ} \mathrm{C}$ and $\pm 3 / 4^{\circ} \mathrm{C}$ at room temperature and over a full $-55^{\circ} \mathrm{C}$ to $150^{\circ} \mathrm{C}$ temperature range. It is also less costly by trimming calibration at the wafer level (Texas Instrument, 2017).

The hot water discharge NC solenoid valve is controlled by simultaneously monitoring and comparing module surface and rear (heat exchanger) temperatures. Therefore, two (2) LM35, each dedicated to monitor modules surface and rear temperatures, are required. The output voltage for LM35 is converted to temperature in degree Celsius $\left({ }^{\circ} \mathrm{C}\right)$ using the Eq. (1) as proposed by Kumar et al. (2010)..

$$
\operatorname{Temp}\left({ }^{\circ} \mathrm{C}\right)=\left(\frac{V_{\text {out }(L M)} \times 100 \%}{1}\right)
$$

The output signals, $\mathrm{V}_{\text {out(LM) }}$ for LM35 sensors are configured as input signals for port A of ATmega32 microcontroller, as thus shown in Fig. 1. The LM35 basic centigrade temperature sensor circuit design is considered for this application. However, due to uncertainties from fluctuations in solar radiation, air motion/wind speed, and other climatic parameters, a capacitor filter is introduced. As given in Eq. (1), the output voltage (i.e. scaling factor, $+10 \mathrm{mV} /{ }^{\circ} \mathrm{C}$ ) is scaled in the controlled program by a factor of 100 .

\section{B. Solenoid Valve Control Unit}

Two $220 \mathrm{~V}$ alternating current solenoid valves are dedicated for hot water discharge and surface cleaning respectively. The hot water discharge valve is controlled based on solar module surface and rear temperature variations. The conceptual design for valve control and the implemented circuit diagram for solenoid valves control is shown in Fig. 2 and Fig. 3 respectively.

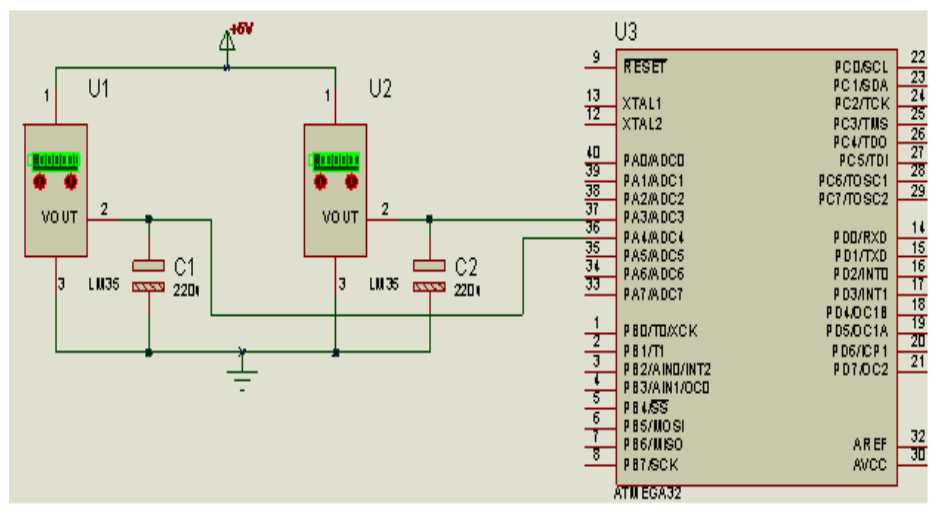

Fig.1: LM35 Temperature Sensing Unit.

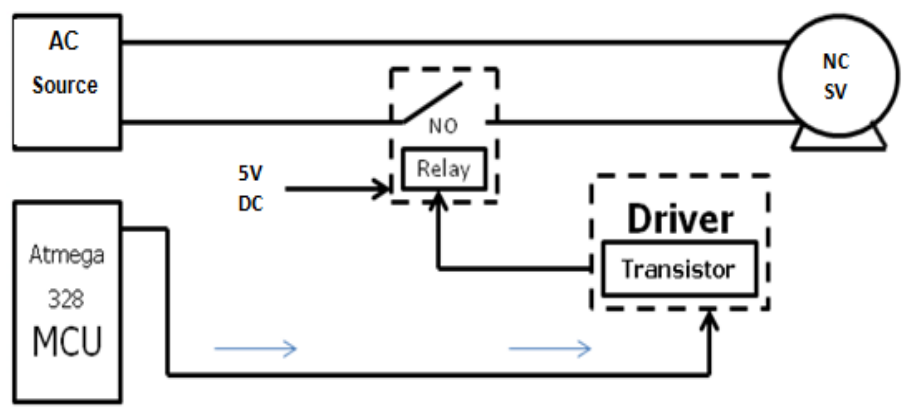

Fig.2: Conceptual for solenoid valve control.

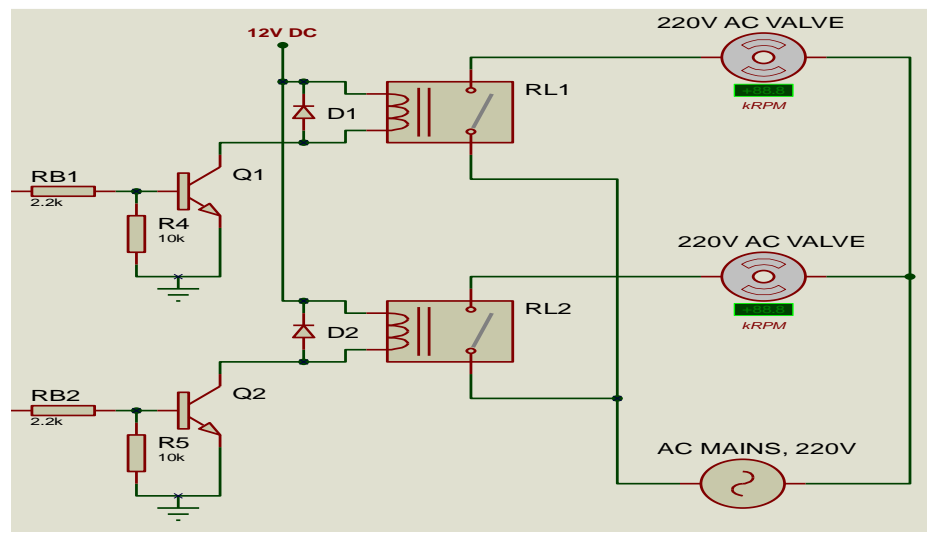

Fig.3:Solenoid valve control implementation hardware unit.

The switching transistors' base resistor values, RB1 and RB2 were computed using Eq. (2),

$$
R B 1=R B 2=\frac{V_{B B}-V_{B E}}{I_{B}}
$$


where $V_{\mathrm{BB}}$ is the transistor's base voltage, $\mathrm{V}_{\mathrm{BE}}$ is the voltage drop across base - emitter (usually given to be $0.7 \mathrm{~V}$ ) and $\mathrm{I}_{\mathrm{B}}$ is the base current. The $I_{B}$ can be determined from eqn (3).

$$
I_{B}=\frac{I_{C}}{\beta}
$$

$\beta$ and $I_{C}$ are transistor DC gain and collector current respectively. The DC gain for D882 transistor is 60 and the $I_{C}$ is the ratio of $\mathrm{V}_{\mathrm{dc}}$ and relay's coil resistance, $\mathrm{R}_{\text {relay }}$ presented in eqn (4),

$$
I_{C}=\frac{V_{d c}}{R_{\text {relay }}}
$$

The parameters $\mathrm{V}_{\mathrm{dc}}$ and $\mathrm{R}_{\text {relay }}$ are known; i.e. $12 \mathrm{~V}$ and 100 $\Omega$. Hence, RB1 and RB2 were both determined as $2.2 \mathrm{k} \Omega$.

The control flow chart for regulating fluid discharge solenoid valve OPEN/CLOSE is shown in Fig. 4.

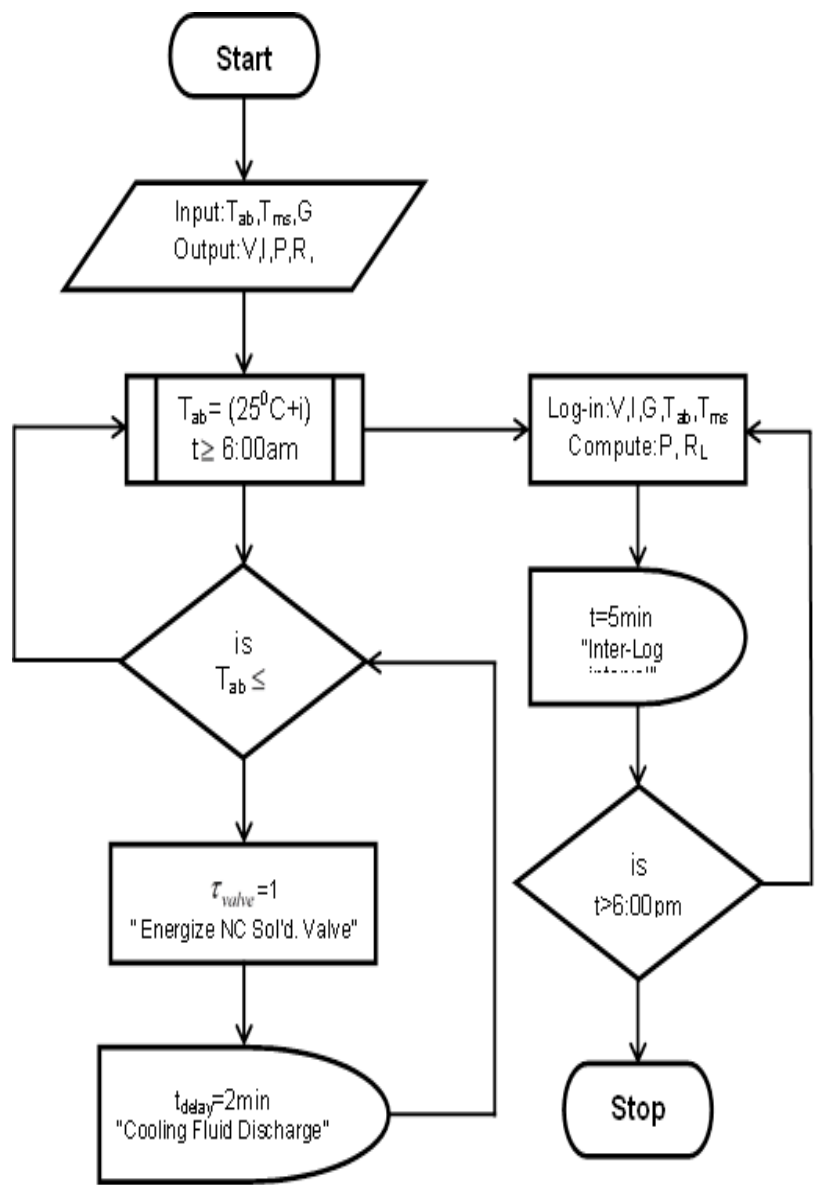

Fig.4: Fluid discharge control flowchart.

\section{Experimental setup/Data collection}

The schematic diagram for the setup and the data collection setup are shown in Fig.5 and Fig.6 respectively. The solar module surface and rear temperature data with their corresponding time were automatically logged by the system.

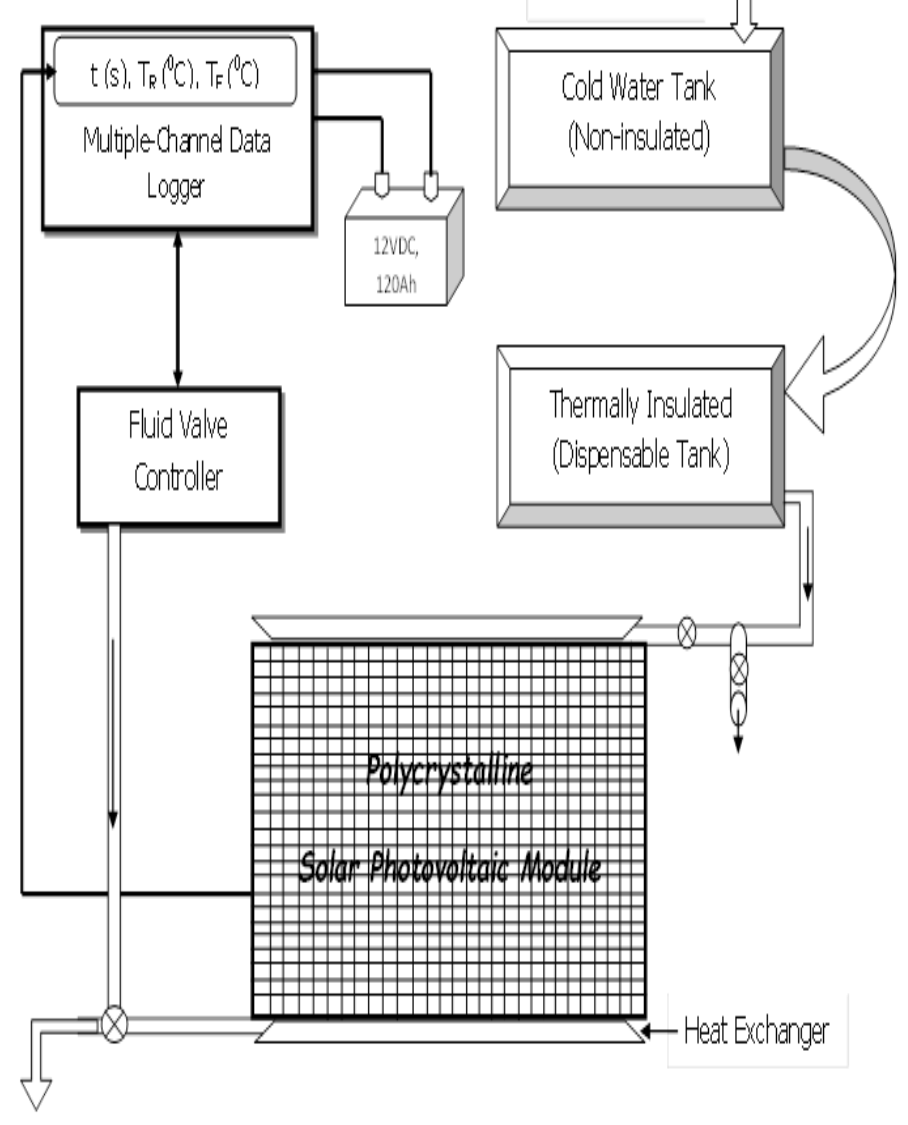

Fig.5: Schematic diagram for the experimental setup.

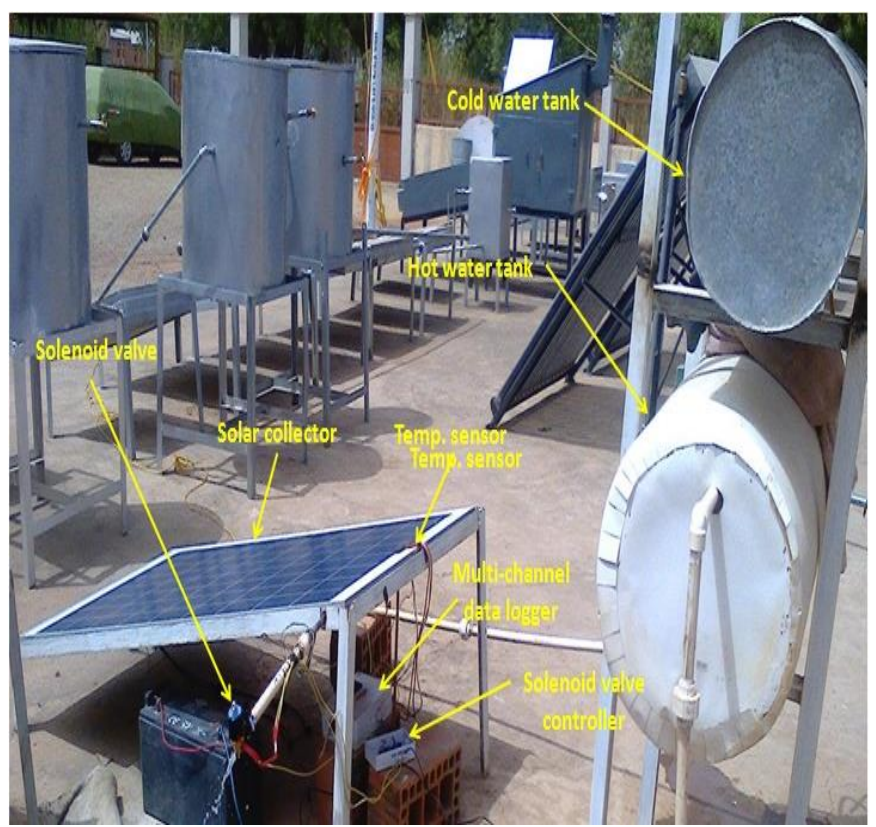

Fig.6: Experimental setup for data collection. 
The system automatically logged the module surface and absorber temperature every $30 \mathrm{~s}$. The data were collected at the demonstration site situated along $13^{\circ} 3^{\prime} 5^{\prime \prime} \mathrm{N}$ and $5^{\circ} 13{ }^{\prime} 53^{\prime \prime} \mathrm{E}$ latitude and longitude respectively between the hours of 06:00 to 16:00 with an inter-data interval of 5 minutes. The logged data were saved on a removable SD card (memory card). However, the data collected between the hours of 10:20 and 16:00 were analyzed, as the solar backup that supply power to the controller and solenoid valve had to be charged to provide adequate power.

\section{RESULTS AND DISCUSSION}

The results are graphically presented using data obtained from solar PV/T system and solar PV/T with valves controller (i.e. smart-base solar PV/T). Fig.7 and Fig.8 are graphical results showing the degree of effectiveness of cooling on solar $\mathrm{PV} / \mathrm{T}$ and smart-based PV/T systems respectively.

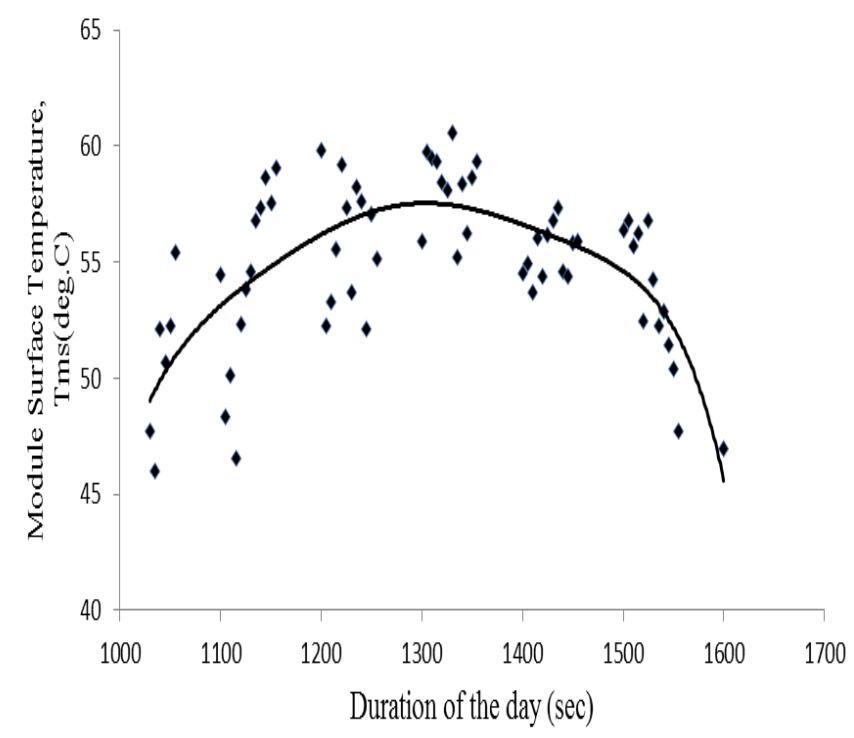

Fig.7: SPV module surface temperature - time relationship.

The maximum temperature of $57.6^{\circ} \mathrm{C}$ and $54.0^{\circ} \mathrm{C}$ were recorded for solar PV/T and smart-based solar PV/T systems. Furthermore, average module surface temperatures recorded for solar PV/T and smart-base PV/T systems were $54.92^{\circ} \mathrm{C}$ and $49.31^{\circ} \mathrm{C}$ respectively. This is an indication that solar module surface temperature whose cooling fluid was controlled by module surface and fluid temperatures present a lower temperature compared to PV/T system.

Fig.9 and Fig.10 shows the variation in solar module absorber temperature with respect to time for solar PV/T and smart-base PV/T system. The results obtained are relatively similar in term of the trends, that is, the absorber temperatures initially appeared to increase as the day advances and later maintain a stable temperature with respect to varied time.

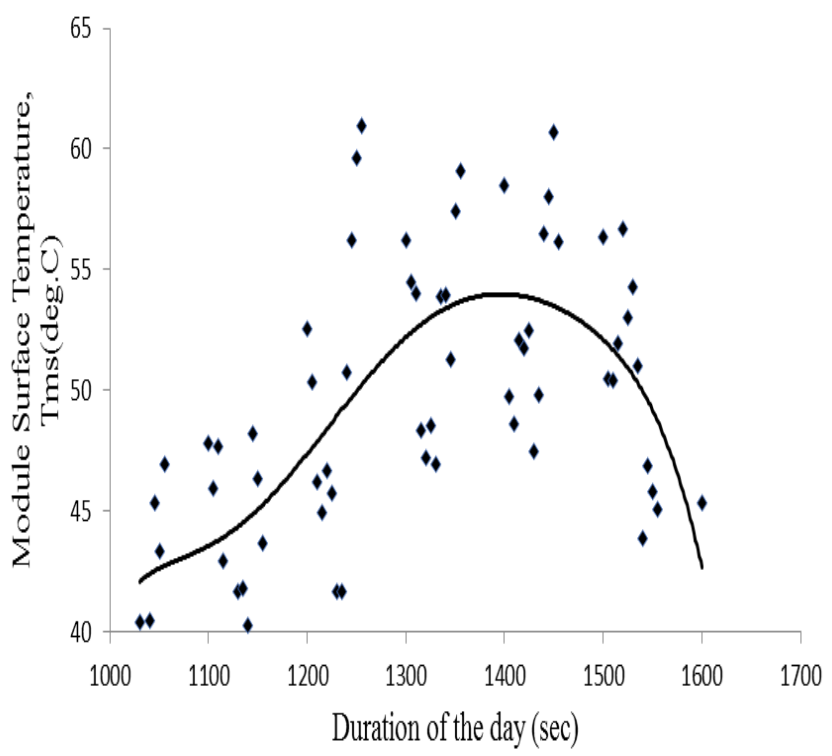

Fig.8: Smart-based SPV/T module surface temperature - time relationship.

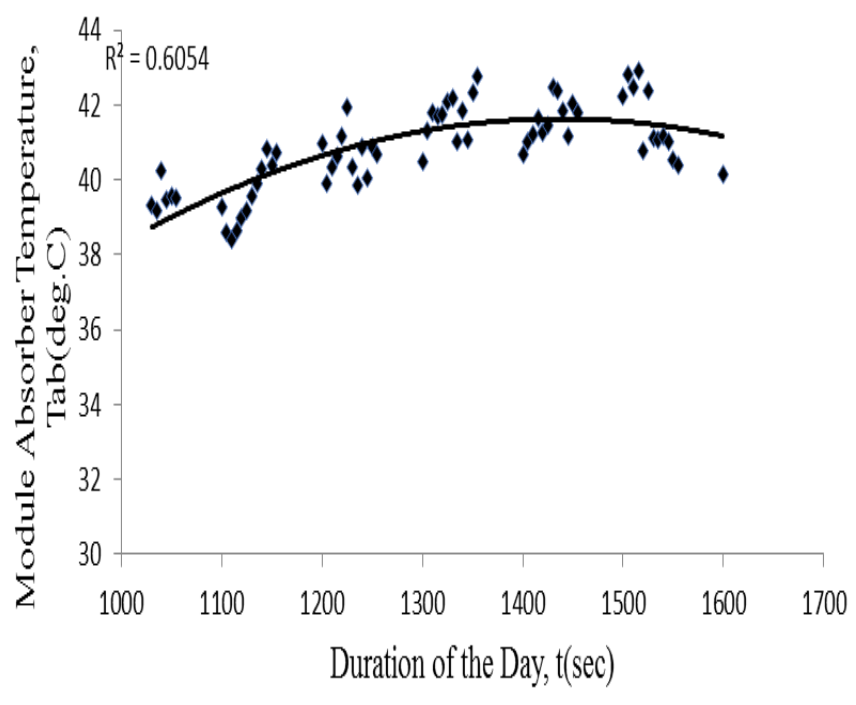

Fig.9: SPV/T module absorber's temperature - time curve fitting.

However, the change in absorber temperature with respect to time is much lower for SPV/T system as compared to temperature controlled SPV/T. From the results presented in Fig.9 and Fig.10, it obvious that absorber temperature for SPV/T attained a stable state much earlier than temperaturecontrolled SPV/T. This implies that the heat transfer between the absorber or heat exchanger and module solar cells (or surface) is less than that of temperature-controlled SPV/T. The maximum and mean absorber temperatures of $41.63^{\circ} \mathrm{C}$ and $40.87^{\circ} \mathrm{C}$ were recorded for solar PV/T (i.e. from Figure 9), while $48.30^{\circ} \mathrm{C}$ and $45.51^{\circ} \mathrm{C}$ were recorded for smart-based $\mathrm{PV} / \mathrm{T}$ (i.e. from Figure 10) systems respectively. 


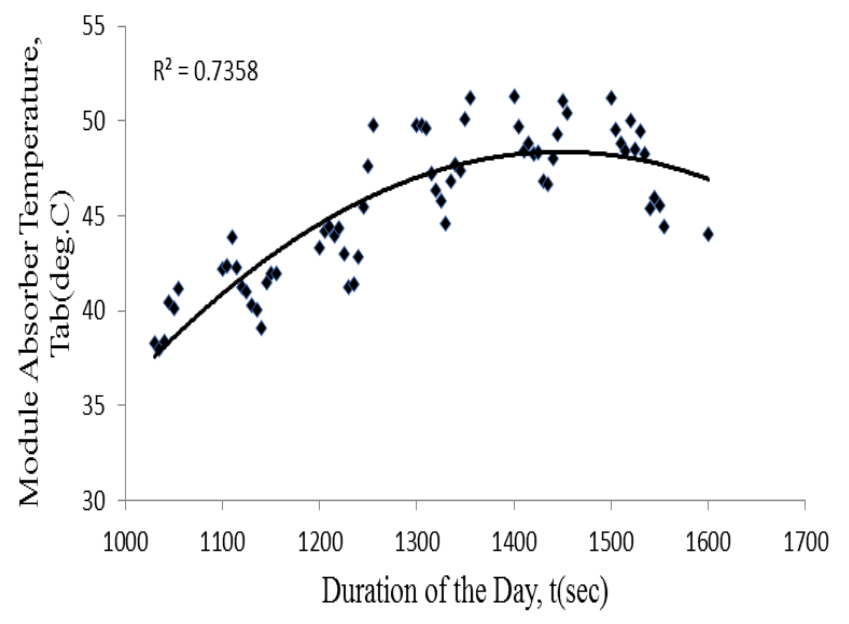

Fig.10: Smart-based SPV/T module absorber's temperature - time curve fitting.

These values have shown that greater amount of heat was absorbed by the smart-base system's absorber as compared with solar PV/T absorber. In addition, SPV/T appeared to attained thermal equilibrium between 13:00 and 15:45. In other words, the temperature of the water and the modules solar cells or surface are equal; the implication is that the heat developed on the module surface would no longer be absorbed by the water. At this point, the cooling process ceases. Contrarily to SPV/T system, temperature-controlled SPV/T system attains equilibrium state at 14:30 and the rate of heat transfer is much higher compared to SPV/T system. This could have resulted in smart-base solar module recording a lower temperature.

Fig.11 and Fig.12 are graphical representations of heat transfer processes between the absorbers and solar modules for solar PV/T and smart-based PV/T systems. Comparing Fig.11 and Fig.12, it can be observed that there is a clear demarcation between solar module and absorber temperatures in Fig.11 whereas in Fig.12, an overlap could be observed. This implies that smart-based system was able to absorb certain quantum of heat energy from the surface of the solar module whereas its counterpart (solar PV/T) might have only absorbed a very small quantity of heat energy, hence accounting for the large gap between the absorber and module temperatures.

On average, the PV module surface temperature lies between 50 and $60^{\circ} \mathrm{C}$ for SPV/T system, whereas for temperature-controlled SPV/T, it lies between 40 and $55^{\circ} \mathrm{C}$. The solenoid valve opens at equilibrium points (between the absorber and PV cells) and thereafter closes in-between two equilibrium. The water temperature is lower compared to module surface temperature in-between these points, which result in enhanced heat transfer. In addition, in-between the equilibrium points, the solenoid valve is disconnected from the power source while the cooling of solar cells taken place. This is responsible for conserved energy in running the valve.

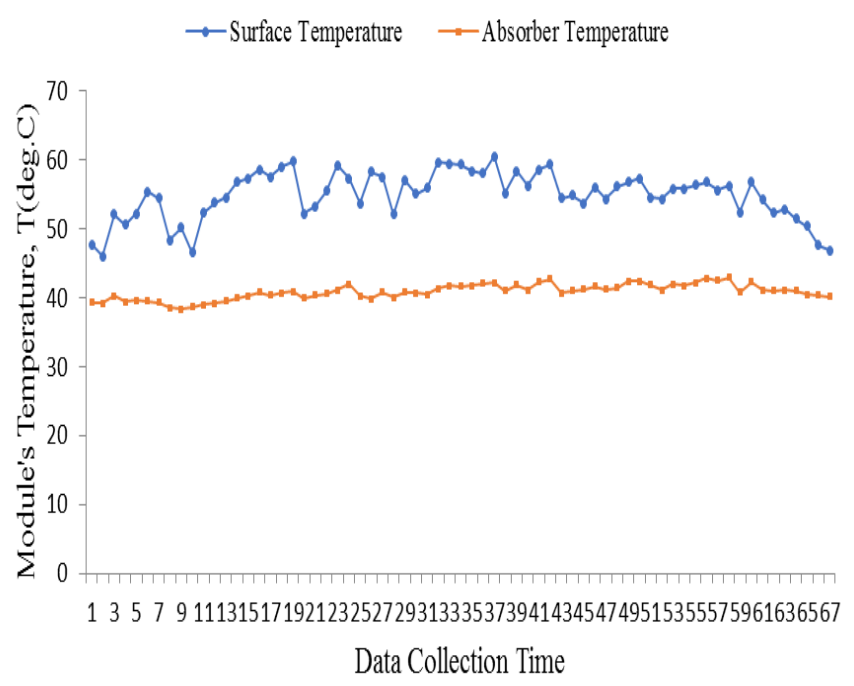

Fig.11: Heat transfer process between absorber and solar module (PV/T).

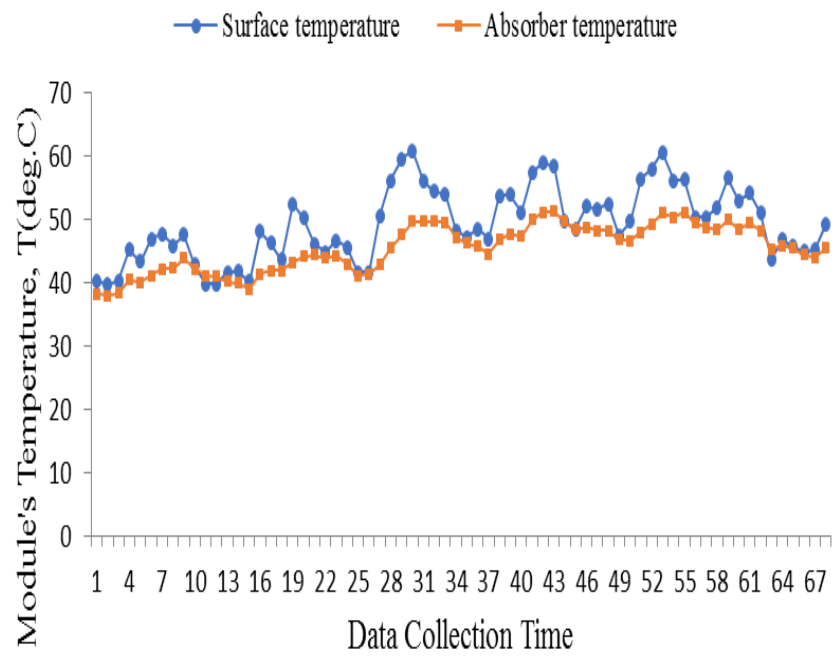

Fig.12: Heat transfer process between absorber and solar module (Smart-based).

The module surface temperature curve fittings for Figures 11 and 12 is presented in Figure 13. The R-square values for the regression models for SPV/T and temperature-controlled SPV/T systems are closed and this implies that the two curve fittings can be compared. The trends for the curves are similar; however, the curve fitting for SPV/T system is projected higher than the temperature-controlled SPV/T curve fitting. 


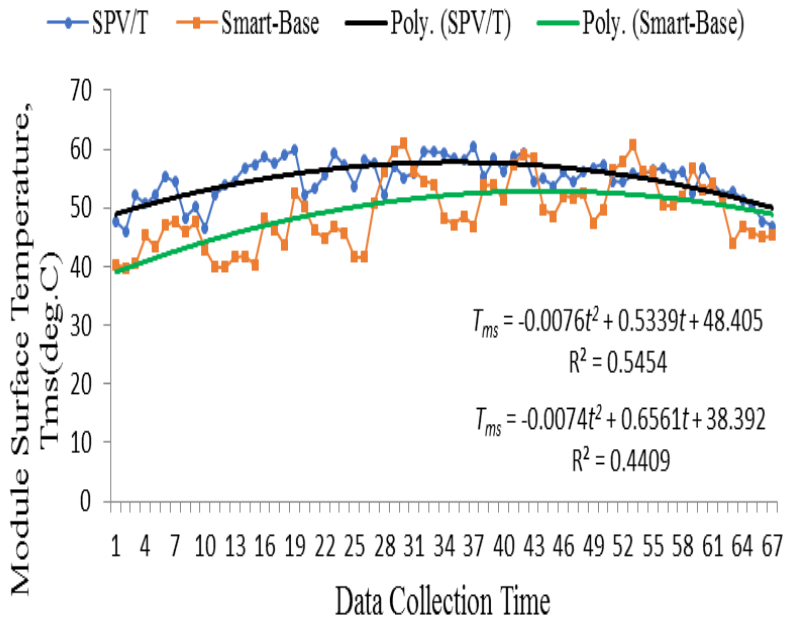

Fig.13: Analysis of temperature variation between smart-based and SPV/T systems.

With SPV/T system curve fitting projected higher than SPV/T, it obvious from Figure 13 that the module surface temperature for SPV/T system is higher throughout the data collection time. This implies more elevated temperature for SPV/T system as compared with temperature-controlled SPV/T system. The percentage by difference of elevated temperature between two system can be ascertain through determination of area under the curves of Figure 13. That is, for temperature-controlled SPV/T,

$$
\begin{gathered}
T_{m s}=-\left(7.4 \times 10^{-3}\right) t^{2}+\left(6.561 \times 10^{-1}\right) t+38.392 \\
\ldots .(5) \\
A_{p v / t}^{\text {smart }}=\int_{L}^{U}\left\{-\left(7.4 \times 10^{-3}\right) t^{2}+\left(6.561 \times 10^{-1}\right) t+38.392\right\} d t
\end{gathered}
$$

In order to simplify the evaluation, the lower and upper limits were assumed to as 0 and 5, instead of 1 and 67. Evaluating equation (6) resulted in

$$
A_{p v / t}^{\text {smart }}=199.85 \text { unit }^{2}
$$

Also, the area under solar PV/T curve fitting is

$$
\begin{gathered}
A_{p v / t}=\int_{L}^{U}\left\{-\left(7.6 \times 10^{-3}\right) t^{2}+\left(5.339 \times 10^{-1}\right) t+48.405\right\} d t \\
A_{P V / T}=248.40 \text { unit }^{2}
\end{gathered}
$$

Hence, smart-based PV/T system was operated at a lower temperature compared to solar PV/T. That is, $10.84 \%$ lower in term of surface temperature than solar PV/T.

\section{CONCLUSION}

The solar photovoltaic module's surface-to-rear temperature-controlled solenoid valve was developed and its performance evaluated. The system was observe to regulates cooling fluid by energizing the solenoid valve under module's surface and rear temperature difference of less than or equal to $1.5^{\circ} \mathrm{C}\left(\mathrm{T}_{\mathrm{s}}-\mathrm{T}_{\mathrm{r}} \leq 1.5^{\circ} \mathrm{C}\right)$. The module surface temperature and absorber temperatures were automatically logged under 30 seconds with corresponding date and time. However, inter-data interval of 5 minutes was chosen. Average module surface temperatures of $49.31^{\circ} \mathrm{C}$ and $54.92^{\circ} \mathrm{C}$ were recorded for the smart-based $\mathrm{PV} / \mathrm{T}$ and solar $\mathrm{PV} / \mathrm{T}$ systems respectively.

This is an indication that there was $5.38 \%$ reduction on smart-based PV/T modules surface temperature as compared with solar PV/T system surface temperature. In term of the overall surface temperature of the systems, the module surface temperature for temperature-controlled SPV/T system was determined to be $10.8 \%$ much lower than that of SPV/T system. The heat transfer process between the absorbers and module surface is found to be more effective for temperaturecontrolled SPV/T system than SPV/T system. Through intermittent ON/OFF or OPEN/CLOSE of the solenoid valve, the energy required for driving the solenoid valve, as well as of powering controllers has been conserved.

\section{REFERENCES}

Bashir, M.A.; Ali, H.M.; Amber, K.P.; Bashir, M.W.; Ali, H., et al. (2018). Performance Investigation of Photovoltaic Modules by Back Surface Water Cooling. Thermal Science, 2(6A): $2401-2411$.

Calebe, A.M.; Licinio, M.S.; Aylton, J.A. and Wesley, P.C. (2017). Increasing Photovoltaic Panel Power Through Water Cooling Technique. Transactions on Environment and Electrical Engineering, 2(1): 60 - 66.

Castanheira, A.F.A.; Fernandes, J.F.P. and Branco, P.J.C. (2017). Demonstration Project of a Cooling System for Existing PV Power Plants in Portugal. Applied Energy, 211(2018): 1297 - 1307.

Ceylan, İ.; Gürel, A.E.; Demircan, H. and Aksu, B (2014). Cooling of a Photovoltaic Module with Temperature controlled Solar collector. Energy and buildings, 72(1): 96 101.

Claros-Marfil, L.J.; Padial, J.F. and Lauret, B (2016). A New and Inexpensive Open Source Data Acquisition and Controller for Solar Research: Application to a Water-Flow Glazing. Elsevier - Renewable Energy, 92(1): 450 - 461.

Dinçer, F. and Meral, M. E. (2010). Critical Factors that Affect Efficiency of Solar Cells. Smart Grid and Renewable Energy, 1(1): 47 - 50. $\quad$ Dorobanțu, L.; Popescu, M. O.; Popescu, C. L. and Crăciunescu, A. (2013). Experimental Assessment of PV Panels Front Water Cooling Strategy. Paper presented at International Conference on Renewable Energies and Power Quality (ICREPQ), Bilbao, Spain. X(11): 1009 1012. 
Kabeel, A.E.; Abdelgaied, M. and Sathyamurthy, R. (2019). A Comprehensive Investigation of the Optimization Cooling Technique for Improving the Performance of PV Module with Reflectors Under Egyptian Condition. Solar Energy, 186(2019): 257 - 263.

Kaya, M. (2013). Thermal and Electrical Performance Evaluation of PV/T Collectors in UAE. M. Sc. Thesis. KTH School of Industrial Engineering and Management Energy Technology, UAE.

Khan, M.A.; Ko, B.; Nyari, E.A.; Park, S.E. and Kim, H.J. (2017). Performance Evaluation of Photovoltaic Solar System with Different Cooling Methods and a Bi-Reflector PV System (BRPVS): An Experimental Study and Comparative Analysis. Energies. 10(826): $1-23$.

Kumar, A.; Singh, I. P. and Sud, S. K. (2010). Design and Development of Multi-Channel Data Logger for Built Environment. Paper presented at International MultiConference of Engineers and Computer Scientist, Hong Kong. 2(1): $1-6$.

Kumar, B.P.; Winston, D.P.; Pounraj, P. and Manokar, A.M (2017). Experimental Investigation on Hybrid PV/T Active Solar Still with Effective Heating and Cover Cooling Method. Elsevier - Desalination, 435(1): 140 - 151.
Rawat, P.; Debbarma, M.; Mehrotra, S. and Sudhakar, K. (2014). Design, Development and Experimental Investigation of Solar Photovoltaic/Thermal (PV/T) Water Collector System. International Journal of Science, Environment and Technology, 3(1): 1173 - 1183.

Texas Instruments (2017). LM35 Precision Centigrade Temperature Sensors. Available online at: www.ti.com. Accessed on August, 2018.

Tobnaghi, D. M.; Madatov, R. and Naderi, D. (2013). The Effect of Temperature on Electrical Parameters of Solar Cells. International Journal of Advanced Research in Electrical, Electronics and Instrumentation Engineering, 2(1): 6404 - $6407 . \quad$ Tsoho, I. Y. (2014). Design, Construction and Performance Evaluation of Thermosiphon Solar Photovoltaic/Thermal System. Unpublished M.Sc. Thesis, Department of Physics, Faculty of Science, Usmanu Danfodiyo University, Sokoto, Nigeria.

Wim, G. J. V.; Ronald, J. V. Z. and Herbert, A. Z. (2004). PV Thermal Systems: PV Panel Supplying Renewable Electricity and Heat. Progress in Photovoltaics: Research and Application, 12(1): 415 - 426. 